\title{
ANALYSIS ON ALTERNATE UNIVERSE POPULARITY'S EFFECT ON DIGITAL-ERA SOCIETY'S READING HABIT IN PHILOSOPHICAL PERSPECTIVE
}

\author{
Anggi Agustine ${ }^{1}$, Azahra Dian Jeanza ${ }^{2}$, Deva Tio Pambudi ${ }^{3}$, Moses Glorino Rumambo Pandin ${ }^{4}$ \\ English Literature Study Program, Faculty of Humanities, Universitas Airlangga \\ Department of English Literature, Faculty of Humanities, Universitas Airlangga \\ anggi.agustine-2020@ fib.unair.ac.id \\ azahra.dian.jeanza-2020@ fib.unair.ac.id \\ deva.tio.pambudi-2020@fib.unair.ac.id \\ moses.glorino@fib.unair.ac.id
}

\begin{abstract}
In the current digital era, internet access became easier moreover with the new $5 G$ technology. Some parts of the society, namely the Millenials and Gen-Z, have been exposed to the said technology since they were in school. Creative ideas poured intensively by them as a result of said technology; one of them being in literature, i.e. popular literature. Everyone is able to become a writer or just to read someone else's work. To complement, internet can also be used as a realization of our imagination. The chance is then exploited by fans of some fandom who want to realize their creativity in form of fictional works to create satisfaction and joy both for writers and readers. Considering that, fanfiction emerges and receives attention because of its uniqueness. Previous researches on fanfiction have shown how fanfiction became exist in society. For that reason, we are interested to study whether there is a relation between the popularity of fanfiction with society's reading habit. Moreover, we try to discover factors that influence this habit. We found that the popularity indeed has a relation with reading habit, eventhough not entirely influences it. Furthermore, we also compare fanfiction's popularity with other types of literature to measure how popular fanfiction is in the society.
\end{abstract}

Keywords: Pop culture, fanfiction, reading habit, literacy 


\section{Introduction}

Indonesian people's interest in reading is at a low percentage. This statement was supported by data on international literacy rankings conducted by Central Connecticut State University (2016) and published in the article Most Literate Nations in The World, which explains that Indonesia is ranked 60th out of 61 countries that participated in a survey about people's reading interest in a Country. Mustafa (2012) in Dini (2018) shows that when measured by numbers 1 to 7, the reading interest of the Indonesian people in several provinces such as Riau, South Kalimantan, East Kalimantan, South Sulawesi, and North Sulawesi only reached an average of 3.2. The survey results above show evidence that the reading interest of the Indonesian people is still relatively low.

According to Mustafa (2012) in Dini (2018), one of the factors that cause people's reading interest to decline is the price of books which are difficult to reach by most Indonesian people. With a high price, buying a book becomes a heavy consideration because the costs incurred can be used for other, more important things.

However, the problem now has a bright spot. Dini (2018) explained that in an alldigital age with rapid technological developments, it can considerably impact various aspects of people's lives. Various tools such as gadgets, laptops, or computers now dominate as devices that every home must own because their technology can facilitate human needs. One of the uses of these tools is to channel one's talent or imagination to be shown to the public via the internet on these sophisticated devices.

The ability of human imagination and creativity has given birth to new works that are diverse and varied, coupled with the support of the current advances in technological developments that greatly assist humans in the process of making a work. With gadgets, one no longer needs a brush, pencil, and paper to draw because there are applications that can help us to draw just by moving a finger on the phone screen, as well as literacy, one does not need to buy a book first if we want to read. Dini (2018) states that there are already many platforms or applications in the internet world that do not charge a penny to download or access them. One application or platform that is widely used is a free book reading application and can be saved. Books or written works contained in platforms or applications are also very diverse, from official books that are printed and licensed by copyright to writings poured out on the internet created for entertainment purposes only. Of course, this opportunity is well utilized by the wider community, fans, or fans. Fans can pour their 
imagination inspired by their idol to be realized into a visual, audiovisual, or written work. One fanwork that has the most interest is his written work, or what is known as fan fiction.

Fanfiction has the same essence as other fiction writing, and the difference is the author and inspiration in the story or characters. Jamison (2013) defines fan fiction as writing that continues, interrupts, re-imagines, or repeats stories or characters that others have written. Duffet (2013) writes that fan fiction is created by fans inspired by favorite objects for a broader definition. Fanfiction is not always inspired by stories or characters that have been created but can also be inspired by their idols, such as celebrities, artists, athletes, internet celebrities, and so on. This fan fiction writing has many genres like fiction in general, but one genre that has much attention is Alternate Universe or AU. This unique genre is a story with a different plot from the original life of the characters. Shannon Sauro (2019) describes AU as a fan fiction story that changes the original elements of the characters included in the story, such as changing their gender, race or ethnicity, occupation, name, and social status. In other words, AU is a story that has a process of "reshaping the narrative to reflect better the diversity of perspectives (imagination) and experiences" (Thomas and Stornaiuolo 2016, p. 314).

Famous for its unique and relaxed language style and a light plot that presents a slice of life stories, AU has many fans. The majority of AU's readers come from Twitter users. Some of the AUs that get much attention are Butterflies by @alesacakes which has 151,000 likes and 54,700 Retweets; Azzamine by @jupiww, which gets 211,000 likes 98,800 Retweets; and the fictional 2.578.0 kilometers by @jenovelized, which gets 85,200 likes and 48,100 Retweets. Many figures prove that AU has a tremendous and certainly diverse readership level. Easy access to reading $\mathrm{AU}$ is one of the reasons why the fanfiction genre has thousands of viewers, especially in the digital era, where everything can be accessed via the internet. From this, a question arises whether the percentage of AU's popularity affects people's reading interest, although it is still a debate whether this fan fiction work is a modern literary work that is useful for readers or just writing to satisfy the imagination of fans.

The description of the popularity of AU, which has an impact on people's reading interest, will be analyzed based on four indicators that determine a person's reading interest proposed by Dini (2018), namely the frequency of a person reading books or other readings, the duration of time a person spends doing reading activities, the number of collections of stories. Possessed, motivation to read, and feelings of pleasure when reading. 
This question becomes an interesting topic for further research. Moreover, analysis of fan fiction is still rarely done. This statement shows how the interest or satisfaction of the people presented in writing can affect their reading interest and the popularity of a work of fiction. From this statement, a deeper analysis is needed to find answers to whether fiction created by fans can influence people's reading interest in writing and examine it using the perspective of the philosophy of science.

\section{Theoretical basis}

The researcher uses a value judgment theory approach to axiology. The value consideration in question is aesthetic value. Researchers stick to Eaton's argument in Arslan, Esmer, and Aktas (2020), which states that acceptance of work must go through social construction, which means that each individual's assessment of the work can vary from one another. For example, if individuals listen to music, watch movies, read novels, they will discuss how high their aesthetic value is with other people. Furthermore, Asch in Arslan et al. (2020) added that external factors influenced the acceptance of these values, which the researchers concluded influenced popularity in society. What is meant is that the majority of ratings influence the level of acceptance by the community.

As in Consoli (2020), Aesthetic judgments only represent the individual's personal feelings and explain the individual's attitude towards the work. Consoli (2020) added that the problem in this assessment lies in how hedonic values are obtained through sensory information. Based on this, Consoli (2020) assumes that aesthetic evaluation is reduced to just pleasure or satisfaction with that aesthetic. The researcher wants to identify and analyze respondents' assessments in surveys and interviews and refer to relevant literature data based on this explanation.

The unique and relaxed language style and a light plot that presents a slice-of-lifethemed story (the value of life) cause AU to have many fans. The majority of AU's readers are Twitter users. Some of the AUs that got much attention was Butterflies by user @alesacakes which had 151,000 likes and 54,700 retweets; Azzamine by user @jupiww, which got 211,000 likes 98,800 retweets. Furthermore, fiction 2.578.0 kilometers by user @jenovelized received 85,200 likes and 48,100 retweets. The achievement of AU's titles proves that AU has a large and varied number of readers. We believe in the ease of access to reading $\mathrm{AU}$, which causes the fanfiction genre to have thousands of viewers, especially in the digital era where everything can be accessed via the internet. Therefore, the question 
arises if the percentage of AU's popularity affects people's reading interest. However, there is still debate if AU can be categorized as a modern literary work that is useful for readers or just writing to satisfy the imagination of fans.

This question becomes an interesting topic for further research. This question shows how the interest or satisfaction of a writer that he presents can affect people's reading interest and the popularity of fiction literary works. Through this statement, a deeper analysis is needed to find answers about whether or not fiction created by fans can influence people's reading interest and examine it using the perspective of the philosophy of science.

Researchers are optimistic that AU can make people more selective, intelligent, and wise readers. The researcher also hopes that by completing this research, we can promote the establishment of reciprocal relationships between readers and writers to collaborate in writing literary works so that they become more varied and of interest to the broader community.

\section{Research methods}

This study uses a mixed-method approach to obtain data from surveys and reference sources from scientific papers and articles. The type of research used is predictive based on current phenomena supported by scientific articles and relevant papers arguments. Predictive research aims to predict future events or impacts due to variable patterns (Waljee, Higgins \& Singal, 2014). Predictive research uses statistical methods and/or data processing techniques without preconceived theoretical constructs. In this study, the researcher will put forward his predictions and then prove them using the data obtained and discuss the impact of the actual data. We chose this research method because the researchers wanted to prove and test the goal, namely the prediction that the existence of AU increases people's reading interest in the digital era, and the reference sources used can strengthen arguments or predictions and add research information.

The data collection technique used by the researcher is a specific population survey, interviewing respondents at random and anonymously and referring to relevant literature data. The collected survey questionnaires will be analyzed using statistical analysis methods. Researchers will process the data by considering the number of respondents stating how often they read, how many titles, and how they felt.

The researcher will then generalize the opinion and/or opinion of the survey and interview respondents on the popularity of AU on people's reading interest. To support these 
generalizations, researchers will conduct a literature study so that these generalizations have a stronger stand.

Researchers become the primary tool in this study which is then supported by research instruments in data collection and processing. First, the researcher will present (1) the results of a specific population survey, (2) the results and analysis of anonymous, randomized interviews, and (3) the results of reference to literature data to support the results (1) and (2). Furthermore, researchers will use tables to present the processed results of the survey. Next, the researcher will describe and process the data into a narrative description. For the interview results, the researcher will also conclude each respondent and conclude on all respondents' answers. Next, the researcher will analyze and prove whether or not there is a correlation between the level of interest in reading and the popularity of AU by reviewing the results of surveys, interviews, and previous scientific references.

\section{Discussion}

Our research and discussion results come from three (3) sources: a specific population survey, anonymous, randomized interviews, and references to related literature data.

\subsection{Survey}

This survey was conducted from November 20, 2021, until next week. The survey shows that, on average, the respondents answered 'often read AU,' and only a small proportion did not read AU often. This trend can show that, according to them, AU is very popular right now. The majority of respondents stated that AU's popularity resulted from packaging the light and easy storyline. In addition, the platform used by the author is social media, which is often used by the Indonesian internet community, namely Twitter. In table (1), we present the opening survey questions regarding the popularity of AU and whether or not they often read or not read AU.

Tabel 1.

How often respondents read $A U$ and whether or not $A U$ is popular

\begin{tabular}{|l|l|l|}
\hline & $\begin{array}{l}\text { Do you often read } \\
\text { AU? }\end{array}$ & $\begin{array}{l}\text { Are AU } \\
\text { popular? }\end{array}$ \\
\hline Yes & $97,6 \%$ & $84,5 \%$ \\
\hline No & $2,40 \%$ & $15,5 \%$ \\
\hline
\end{tabular}

In tables (2) and table (3), we present respondents' opinions on why AU can be widespread and how often respondents spend their time reading AU in a week. In addition 
to table (2), we use free-fill questions and simplify the results by taking the main points of the responses. Most of the respondents stated that AU has a light language style, is exposed to digitization, the majority is free and easy to find. In addition, respondents also stated that there were visualizations made by AU writers who used the fake chat feature or screenshot chat so that readers felt this was an effective way to increase their desire to continue reading the story even though they had to wait for a sequel or prequel if the story was not finished. Furthermore, the survey results also stated that respondents answered 'uncertainly' or did not have a routine of reading AU within the last week the survey was conducted. However, about a quarter of the respondents stated that they could read AU more than five times a week.

Tabel 2.

Respondents' Opinion on the Reasons for AU's Popularity
\begin{tabular}{|l|l|}
\hline Plot & $10 \%$ \\
\hline $\begin{array}{l}\text { Unpredictability of the } \\
\text { story }\end{array}$ & $4 \%$ \\
\hline Visualization & $18 \%$ \\
\hline Language style & $21 \%$ \\
\hline Characters & $16 \%$ \\
\hline Light & $11 \%$ \\
\hline Free/easy access & $21 \%$ \\
\hline
\end{tabular}

Tabel 3.

Frequency of Respondents Reading AU

(in Percent)

\begin{tabular}{|c|c|c|c|}
\hline Uncertain & $\begin{array}{c}\text { Three times } \\
\text { a week }\end{array}$ & $\begin{array}{c}\text { Five times a } \\
\text { week }\end{array}$ & Other \\
\hline $45,1 \%$ & $14,6 \%$ & $25,6 \%$ & $14,7 \%$ \\
\hline
\end{tabular}

Most of the respondents felt the ease of access in finding AU literature. They stated that AU could fill spare time rather than not doing anything. This feeling is evidenced by a statement said by one of the respondents,

".. the story is exciting, it can relieve stress, lift the mood, and fill spare time, as an escape from fatigue, looking for a new perspective on life."

Respondents can find a place to 'escape' from all their fatigue and tiredness to find a new perspective. The reason given by the respondents was that AU's story was packaged attractively by choosing a popular idol as the story's character. They think that popular idols can excite their passion for reading AU. 
The feeling sensation generated after or while reading AU makes readers loyal to all parts of the story presented - starting from the original story, the sequel to the prequel, and even the crossover. About ninety percent of respondents felt enthusiasm and the rest felt normal. Furthermore, the enthusiasm felt by AU readers is a feeling generated when waiting for a follow-up story or a new episode.

One respondent stated, "... because I think AU has different storytelling from the others. The depiction of the characters and the plot is lifelike and can bring the reader into the story more."

We can draw a temporary conclusion that the description of AU's story is different from the others because AU tends to carry an exciting concept and is easy or light to read. Readers can feel the ease of reading the story by imagining the idol figure who acts as the main character in the story. Readers can imagine what they want through the plot provided by the author.

Table (4) presents free-choice questions with respondents choosing more than one answer. Respondents chose social media as a straightforward place to find AU stories. Online reading platforms, such as Wattpad and others, take second place as AU's reading source, with the remainder coming from the internet, friends, and other sources.

Tabel 4.

Sources of Respondents in Searching for AU Readings (in Percent)

\begin{tabular}{|c|c|c|c|c|}
\hline Social & Inter-net & friends & $\begin{array}{c}\text { Online } \\
\text { reading } \\
\text { platform }\end{array}$ & Other \\
\hline $90,2 \%$ & $24,4 \%$ & $26,8 \%$ & $46,3 \%$ & $2,4 \%$ \\
\hline
\end{tabular}

One respondent stated, "...because AU is getting popular on Twitter, so I tried to read it."

The rising trend of social media can support this statement during the pandemic. The majority of respondents are interested in reading AU because it has a light plot and a story that makes them entertained. AU as an entertainer took second place and was followed by character selection by the writer to be the actors in the story. The next position is filled with writing styles, varied genres, stress relievers, and spare time fillers. Table (5) presents the percentage of reasons why respondents became interested in and interested in reading AU. 
Tabel 5.

Reasons Respondents Interested in AU

\begin{tabular}{|c|c|}
\hline Genre Variations & $6 \%$ \\
\hline Stress reliever & $4 \%$ \\
\hline Free time filler & $7 \%$ \\
\hline Story writing style & $7 \%$ \\
\hline Plot & $43 \%$ \\
\hline Character Selection & $13 \%$ \\
\hline Entertainer & $20 \%$ \\
\hline
\end{tabular}

\subsection{Interwiew}

We interviewed three sources randomly and anonymously. Therefore, we gave them pseudonyms, namely Lisa, Lula, and Vivi.

\subsubsection{Informant 1 (Lisa) ${ }^{1}$}

The researcher conducted a written interview through a private chat on the Whatsapp application on December 5, 2021, at 13.40 WIB. Lisa is a new student who is 19 years old and currently pursuing higher education at a public university in Surabaya.

Lisa became interested in reading AU because AU had a shorter story. However, before entering the world of AU stories, she first read literary works such as novels and other fanfiction. According to her, AU is a digital literary work that is interesting and tends to be addictive to read because of the unmissable storyline and requires the reader to follow every part of the story. In addition, he also added the benefits of $\mathrm{AU}$, which can make her know some foreign terms, and stated the potential of AU, which can increase people's reading interest if AU is packaged more attractively.

"Several times I know some foreign terms such as the profession of criminal profiler and his job description from reading the AU."

Lisa reads AU's story because it has a plot and language style that is easy for all people to understand. In addition, the story's packaging becomes interesting with

\footnotetext{
${ }^{1}$ Interview with Lisa (19 years old), Universitas Airlangga, Surabaya, 5 December 2021.
} 
the use of famous figures who then have a significant influence in attracting the wider community's interest. He knows AU from friends' information, and AU often appears on his Twitter timeline. According to her, AU readers will look for friends or interlocutors who are also AU connoisseurs because they want to exchange ideas about the AU they read.

"Most AU readers will look for friends or interlocutors who are also AU lovers. This is due to the urge to exchange ideas about the AU with other people. Most of my friends who enjoy AU also experience the same thing."

One of the AU stories that Lisa reads is a story about a homosexual couple, while the genre she is currently reading is interns. Lisa likes this type of story because it is addictive and can create a very high curiosity. In addition, the story also contains many new things about the intricacies of internships, such as the registration procedure, the work environment, and the new terms she learned.

\subsubsection{Informant 2 (Lula $)^{2}$}

The second informant is Lula. Researchers conducted interviews through WhatsApp private chats on December 5, 2021, at 15.00 WIB. Lula is a 19-year-old student currently studying for a bachelor's degree at a public university in Surabaya. Lula has been an active K-Pop fan since elementary school.

Lula stated that she reads AU more often than other literary works such as fiction novels, poetry, or short stories. According to him, AU has a language style that is fun, light, and easy to understand because he uses word choice in everyday conversation or informal language. Lula added that she often reads AU and feels addicted because the stories that are raised have the characteristics of AU writers. The example he gives is when the author makes fiction with the background of a medical student who is seasoned with slices of life (the value of life) from the character. This is supported by the characters and characterizations that visualize Lula's idol to increase further interest in reading about AU.

"... addicted because of the characters, characterizations, and storylines that make me want to keep reading it even more. Because the characters and stories in AU usually depict my idol as the main character in the story. So my literacy level, especially when reading AU, has improved significantly."

\footnotetext{
${ }^{2}$ Interview with Lula (19 years old ), Universitas Airlangga, Surabaya, 5 December 2021.
} 
The informant added that his peers or fandom friends also have the same interest in AU. Lula thought that she and her friends exchanged stories about AU that they had read and recommended good AUs to each other.

"... we also exchanged stories and recommended good AUs to each other to read."

We asked Lula's opinion about the community's higher interest in reading literacy if AU had a broad reach (not only widespread on one social media platform). She agreed with the statement and added that the public's interest in reading literacy could be even higher if AU uses language that all people can understand. In addition, the various genres of AU can make people choose freely and young, and reading AU does not require significant expenses and the purchase of its physical form like fiction novels in general, making it easier for the public to access these fan fiction stories.

\subsubsection{Informant $3(\text { Vivi })^{3}$}

We interviewed Vivi on WhatsApp private chat on 5 December 2021, 18.00 local time. Vivi is a second-year student and currently has a small online shop. Vivi is nineteen years old and is considered an excellent student.

Vivi stated that they only read AU if its content or story matches their interest. They added that reading AU is the same as reading other literature works, i.e., whether there is a moral value to be taken, both after or during reading, from the story's conflict. They also stated that their will to read is influenced by the story and personal will instead of the existence of AU. They added that if the said works do not interest them, they will find it hard to read and even hesitate.

"... so maybe literacy level of mine most influenced by mood and interest instead of $A U . "$

We also inquire their opinion whether other readers would feel the same as them. They doubted that. Furthermore, they feel that a fanatical reader may be hesitant to read works other than AU. They added that those readers would tend to spend their time reading AU rather than working on more critical academic and/or jobs.

"... take a student, for example, they may be lazy to read their academic books, not studying, then will choose to read AU on their past times."

\footnotetext{
${ }^{3}$ Interview with Vivi (20 tahun), Universitas Airlangga, Surabaya, 5 December 2021.
} 


\subsection{Bibliography Reference}

Fanfiction is a space that brings fans together with their idols, which is unlikely or will never happen in the real world (Fitri Merawati: 2016). Therefore, fans created a unique space to channel their desires and make their idols feel closer because of the role and character of the imagination. AU's language style, which uses everyday language, makes this fan fiction the right place to satisfy readers' desires. Dewi Nurmala, Nila Afningsih, and Mutawaqil Bilah Tumanggor (2019) stated that a unique language style could attract people's hearts. One of the unique characteristics of AU is the style of language. Based on the results of our survey and interviews, readers tend to prefer writing that uses informal (used daily) and prokem (slang) words, such as "lo-gue". The author managed to build the character to be more alive and feel real because the language used is not foreign to us from the choice of words. This statement is supported by the results of a survey of more than a quarter of respondents who said that the light style of language is one of the reasons why AU gets much attention from the public.

Another factor in AU's popularity is the plot. Survey respondents said that the plot or storyline of AU is more exciting and varied and cannot be guessed easily. This is also supported by the selection of characters and how these characters are depicted in the story. The usually popular characters are K-pop singers as appointed by the author with the usernames@salmahadids and @ rennozeria on Instagram. Carvallo and Parra, in a study on the fanfiction community in 2019 , revealed that favourite stories and the number of titles by the author made the author have many followers or readers (Carvallo \& Parra, 2019). In addition, the author profile is the first to influence the number of followers.

The character then becomes the factor expressed by the respondents as what makes them interested in reading AU. This is supported by research on the variety of characters, characterizations, and plots (relationships between characters) in a Harry Potter fanfiction, which is published annually with various plots showing that the trend will continue to rise, including older fanfictions with similar themes (Pianzola, Acerbi, \& Rebora). 2020).

AU or fanfiction readers will always communicate with the author through reader reviews and/or through readers' expressions by citing parts of the story. Furthermore, readers can provide comments or suggestions on the text so that the author can improve the quality of the stories he makes (Koltochikhina, 2020). This reciprocal relationship can then be related to the Reader's Response Theory, which assumes that literary works are in the midst of a relationship between writers and readers, aiming to reveal what literature is and relate it 
to personal experiences experienced (Mart, 2019). In addition, a story can evoke the reader's experience of the story, making them selective or even rejecting old or new works so that it will indirectly regulate what can attract the reader's attention in the future. Readers' responses or reviews are further influenced by context. In this study, we take the context in the plot, language style, and characters. Based on the answers of survey respondents and informants in interviews, the plot becomes the main point that affects their level of interest in reading AU.

Another reason why AU gets much attention from the public is that readers have enough free time to read the stories presented by the author. Readers always have enough free time, and it is not very interesting if it has not filled with something they like. This boredom is commonly referred to as leisure boredom. Iso-Ahola and Weissinger in Diona Putri, W. and Rusli, D. (2021, pp. 3-11) say that leisure boredom is a perception that free time is not enough to meet needs optimally. Someone who can fill spare time will get psychological benefits, but it will be boring when we cannot use that free time with beneficial activities. This helpful activity can be in the form of reading AU stories.

Previously, we thought that AU is a famous literary work that is easy to access in today's digital era. According to the Central Statistics Agency (BPS), in the 2020 national socio-economic survey, as many as 53.73 per cent of Indonesia's population will have internet access in 2020. The high number of internet users reflects a climate of openness to information entry and public acceptance of increasingly advanced technological developments and changes towards an information-based society. From the results of the BPS survey, there are many internet users, mainly social media which is now more likely to be used by Millennials and Generation Z.

According to Seteyo (2019), the virtual world or virtual world is a place for users to form a community based on the agreement of the thoughts they make. Virtual space has no limits for users to disseminate information wherever they want. Therefore, according to him, the virtual world is the right place to be used as a public space.

The most social media users in Indonesia, according to a HootSuite report, there are approximately 170 million social media users in 2021, with the number of social media users increasing to 10 million or around 6.3 per cent of users in the period 2020 to 2021 (Kemp, 2021). As we suspected before, the increase in the number of social media users led to an increase in the number of accesses, one of which was Twitter. Accessing Twitter does not 
have to be expensive; it is even free. The stories presented can usually be searched with specific criteria according to the reader's wishes.

The public's attention to AU then gave rise to various responses. Feeling happy, optimistic, and always excited when doing something is a sense of enthusiasm (Afdhal, 2015). Enthusiasm can encourage people to keep repeating what activities are currently popular. Based on Behaviorism theory in the law of effects stated by Gledler (1991), and put forward by Thorndike, the theory of effects (law of effect), in this case concerning the pleasure of reading AU, states that something pleasant will continue to be repeated and tends not to be repeated. If we do not get that taste (Lisa Herawati, 2021). The community's sense of satisfaction when reading AU causes them to keep repeating the activity, thereby creating a high sense of interest in reading fan fiction.

Based on these theories, the researcher can conclude a temporary meeting point stating that the reader's behaviour results in the desire to read other AU titles. According to Azizah (2014), the emergence of a sense of satisfaction in reading is because the author makes the plot in such a way by exploring more deeply about the characters or idols they use to make the story. In addition, the author wants to create a literary work with a different perspective, plot and setting so that the work can be of high value, which increases the possibility that the reader will return to seek satisfaction when he is feeling tired and/or stressed. In addition to releasing fatigue or stress, most AU readers also satisfy their imaginations on the dissatisfaction with the climax of a film, novel, or the reality of their idol. A few respondents think that AU's popularity only revolves around fans or their market. On the other hand, other literary works also have their readership market. Therefore, researchers are still not sure that the popularity of AU affects the more comprehensive reader to consume readings other than AU but only to confident readers, namely K-Pop, Anime, JPop, and/or Western fans.

\section{Conclusion}

The story created by the author of AU raises a new imagination for fans of the character. Experience in reading digital literary works like this can make other literary writers find ideas so that they can be popular among the wider community. The results of other studies also discuss that respondents enjoy AU's work because they can fill their spare time, so they do not get bored. AU has many benefits for its readers, and according to respondents, AU can provide them with new knowledge that they have never learned before. 
The purpose of this study is to prove the statement that AU can affect people's reading interest, but the results obtained do not show a relationship between AU's popularity and people's reading interest in general. The general public's interest in reading is not significantly affected by the popularity of AU but by the author's reach. This results from the people's reading needs that have not been fulfilled or are not within the scope of the AU writers. The researcher then concluded that two solutions were needed to help increase public interest in reading in general. The first is to expand the readership market by the author so that more people can enjoy his work. The second is to introduce AU by promoting what already exists, namely K-Pop, J-Pop, Anime, and others, to the public. Another alternative solution can be to add variations to the plot, characters, and aspects to increase the reach of readers so that it can help increase public interest in reading in general.

Our suggestions and recommendations for further research are to find and analyze the most appropriate and effective methods to increase reading interest to AU readers, AU writers, and the general public. Further research also needs to review events to be more current and follow the conditions when the research was carried out. 


\section{Bibliography}

Arslan, İ., Esmer, Ş. C., \& Aktaş, M. (2020). The Effect of Conformity Pressure and Ambiguity Intolerance on Aesthetic Judgments. Koç University Undergraduate Psychology Journal, 9, 10-18. https://kuupj.ku.edu.tr/downloads/KUUPJ_9.pdf

Pramong, A. (2019). PERILAKU MEMBACA BACAAN CETAK DAN DIGITAL PADA SISWA SMA DI KOTA SURABAYA (Skripsi Thesis, UNIVERSITAS AIRLANGGA). Retrieved from http://repository.unair.ac.id/id/eprint/81327

Azizah, C. (2014). PERAN KOMUNITAS ONLINE FANFICTION DALAM MENGEMBANGKAN LITERASI MEDIA SEBAGAI PRAKTIK REPRODUKSI KULTURAL (Skripsi Thesis, UNIVERSITAS AIRLANGGA). Retrieved from http://repository.unair.ac.id/id/eprint/28843

Carvallo, A., \& Parra, D. (2019). Analyzing Network Effects on a Fanfiction Community. Eprint ArXiv:1909.02886. https://ui.adsabs.harvard.edu/abs/2019arXiv190902886C/abstract

CCSU News Release. (2016, 09 Maret). World's Most Literate Notions Ranked. [online]. Tersedia: https://webcapp.ccsu.edu/?news=1767\&data.

Consoli, G. (2020). Aesthetic Value and Aesthetic Judgement. The Key Problem for Contemporary Aesthetic Naturalism. Aesthetic Investigations, 4(1), 112-121. https://doi.org/10.5281/zenodo.4415579

Dini, A P. (2018), Pengaruh Penggunaan Aplikasi Bacaan Digital Terhadap Tingkat Minat Baca Di Kalangan Mahasiswa Universitas Airlangga. Jurnal Repository Universitas Airlangga. http://repository.unair.ac.id/id/eprint/72398

Diona Putri, W. and Rusli, D. (2021) 'Pengaruh Leisure Boredom Terhadap Phubbing Pada Remaja Di Kota Padang', Jurnal Riset Psikologi, 2(2021), pp. 1-11.

Duffett, M. (2013). Understanding Fandom: An Introduction to the Study of Media Fan Culture (American First ed.) [E-book]. Bloomsbury Academic.

Kemp, S. (2021, Februari 11). Digital 2021: Indonesia [This report contains all the latest internet stats, mobile stats, and social media stats for Indonesia, but read on below]. HootSuite. $\quad$ Retrieved Desember 23, 2021, from https://datareportal.com/reports/digital-2021-indonesia

Koltochikhina, E. E., \& Tsepkova, A. V. (2020). The Status and Peculiarities of Fanfiction as a Phenomenon of Contemporary Popular Culture. Актуальныле Проблемьл 
https://stfl.conf.nstu.ru/conf2020/documents/\%D0\%A1\%D0\%B1\%D0\%BE\%D1\% 80\%D0\%BD\%D0\%B8\%D0\%BA\%20\%D0\%90\%D0\%9F\%D0\%A1\%D0\%9E2020.pdf\#page=62https://stfl.conf.nstu.ru/conf2020/documents/\%D0\%A1\%D0\%B 1\%D0\%BE\%D1\%80\%D0\%BD\%D0\%B8\%D0\%BA\%20\%D0\%90\%D0\%9F\%D0 \%A1\%D0\%9E-2020.pdf\#page $=62$

Mart, C. (2019). Reader-Response Theory and Literature Discussions: a Springboard for Exploring Literary Texts. The New Educational Review, 56(2), 78-87. https://doi.org/10.15804/tner.19.56.2.06

McCracken, A. (2015). Fic: Why Fanfiction Is Taking Over the World by Anne Jamison. Cinema Journal, 54(3), 170-175. https://doi.org/10.1353/cj.2015.0023

Mustafa, B. (2012). Indonesian People Reading Habit Is Very Low: How Libraries Can Enhance The People Reading Habit. Jurnal Istitut Pertanian Bogor.

Pianzola, F., Acerbi, A., \& Rebora, S. (2020). Cultural Accumulation and Improvement in Online Fan Fiction. Proceedings of the Workshop on Computational Humanities Research, 9, 2-11. http://bura.brunel.ac.uk/handle/2438/21779

Sauro, S. (2019) 'Fan Fiction and Informal Language Learning', The Handbook of Informal Language Learning, (Duffett 2013), pp. 139-151. doi: 10.1002/9781119472384.ch9. Seteyo, D.N. (2019). Literasi Informasi Digital Di Kalangan Mahasiswa Dalam Memanfaatkan Media Sosial (Jejaring Sosial). (Skripsi thesis, UNIVERSITAS AIRLANGGA). Retrieved from http://repository.unair.ac.id/id/eprint/94990

Sutarsih, T., Apresziyanti, D., Wulandari, H., \& Hasyyati, A. N. (2020). STATISTIK TELEKOMUNIKASI INDONESIA 2020. Badan Pusat Statistik. https://www.bps.go.id/publication/2021/10/11/e03aca1e6ae93396ee660328/statisti k-telekomunikasi-indonesia-2020.html

McCracken, A. (2015). Fic: Why Fanfiction Is Taking Over the World by Anne Jamison. Cinema Journal, 54(3), 170-175. https://doi.org/10.1353/cj.2015.0023

$\ddot{u}$ on. (2021, May 8). Twitter. Retrieved December 20, 2021, from https://twitter.com/jenovelized/status/1390989342064054273

Jüpitsr on. (2021, October 16). Twitter. Retrieved December 20, 2021, from https://twitter.com/jupiww/status/1449334642545360898?t=JsU9TnEYbXo5xGleV 9uoYA\&s=19

Ale on. (2021, March 21). Twitter. Retrieved December 20,2021, from https://twitter.com/alesacakes (saat ini akun sedang nonaktif/deactive) 
